\title{
Religious Morality or Moral Religion? : Kantian and Pragmatist Reflections
}

\section{Pihlström, Sami}

Brill

2017-06

Pihlström , S 2017 , Religious Morality or Moral Religion? Kantian and Pragmatist

Reflections . in P Luomanen, A B Pessi \& I Pyysiäinen (eds), Christianity and the Roots of Morality : Philosophical, Early Christian and Empirical Perspectives . Philosophical Studies in Science and Religion, vol. 8 , Brill , Leiden , pp. 65-86 . https://doi.org/10.1163/9789004343535_005

http://hdl.handle.net/10138/310742

https://doi.org/10.1163/9789004343535_005

acceptedVersion

Downloaded from Helda, University of Helsinki institutional repository.

This is an electronic reprint of the original article.

This reprint may differ from the original in pagination and typographic detail.

Please cite the original version. 


\title{
RELIGIOUS MORALITY OR MORAL RELIGION?
}

Kantian and Pragmatist Reflections

\author{
Sami Pihlström \\ Helsinki Collegium for Advanced Studies \& University of Jyväskylä \\ sami.pihlstrom@helsinki.fi, sami.j.pihlstrom@jyu.fi
}

\section{Introduction}

While recent empirical findings strongly challenge the traditional conception of religion as a source or foundation of morality, ${ }^{1}$ it has been (largely non-empirically) ${ }^{2}$ argued by philosophers for a long time that basing morality on religion, or justifying ethical views theologically, leads to a severe misunderstanding of both morality and religion. Perhaps, then, religion should itself be based on morality (if it can be based on anything) instead of offering a ground or basis for morality? Or perhaps the relation between morality and religion should be regarded as a matter of mutual holistic adjustment, with no one-way grounding either way?

In order to pursue these options, this article will first examine the Kantian argument that grounding morality in religion yields a "heteronomous" and therefore misguided conception of morality, whose true core is human autonomy. Kant, however, famously suggested that religious ideas such as God's existence and the immortality of the soul can be defended as "postulates of practical reason" that need to be invoked in order to make sense of the human moral pursuit, even though morality as such does not (and cannot, in order to remain autonomous) presuppose religion or theology. According to Kant, there can be no theological ethics or religious morality, but "moral theology" (which, for Kant, is the only legitimate form of rational theology) is nevertheless available to the critical thinker. Versions of this Kantian idea have been further explored in different ways also in philosophical traditions otherwise relatively far from Kantianism, including William James's and John Dewey's pragmatism. ${ }^{3}$ On the basis of

\footnotetext{
${ }^{1}$ See, e.g., Ilkka Pyysiäinen's contribution to this volume.

2 I must immediately add a qualification here: we will below discuss John Dewey's naturalized philosophy of religion, which is based on the rejection of any sharp dichotomy between empirical science and non-empirical philosophical inquiry.

3 In addition to Kantian and pragmatist perspectives, the Wittgensteinian tradition in moral philosophy and philosophy of religion is potentially an important source here but must unfortunately be set aside in this investigation. For a comprehensive discussion of the relation between ethics and religion from a pragmatist point of view taking into account both Kantian and Wittgensteinian dimensions of these issues, see Sami Pihlström, Pragmatic Pluralism and the Problem of God (New York: Fordham University Press, forthcoming 2012). (The present paper partly summarizes the more detailed reflections available in my book.)
} 
Kantian and pragmatist arguments, it will be suggested in this essay that no serious moral or religious thought can ground morality in religion; on the contrary, religion itself requires continuous moral evaluation. This general position, illustrated with brief discussions of not only the classical pragmatists but also Richard Rorty's neopragmatism, will finally be further developed with special emphasis on "negative" moral concepts, such as evil, which are argued to be both morally and religiously profound and significant.

\section{Kant's critique of traditional theology}

Famously, Immanuel Kant rejected all traditional proofs of God's existence - the ontological argument, the cosmological argument, and the physico-theological ("design") argument - that his rationalist predecessors such as René Descartes and Gottfried Wilhelm Leibniz (among many others) had employed in their attempts to demonstrate theism as a truth of reason. These traditional theistic proofs are examples of reason's natural tendency to seek the "unconditioned" beyond the series of "conditioned" entities and events we come up with in the empirical world. Insofar as we remain at the level of mere "ideas" (concepts), there is no problem, and our tendency to form the idea of the unconditioned - in its various forms - is humanly unavoidable. Problems arise when reason finds itself compelled to postulate the unconditioned object of such an idea. Such a move to a metaphysical unconditioned is, Kant tells us, simply beyond the capacities of human cognition. Human reason's habit of formulating ideas leading to "transcendental illusion" is natural and inevitable, but the theistic proofs are fallacies the critical thinker can and should avoid. ${ }^{4}$

The details of these issues need not concern us here. What we are concerned with is Kant's own moral argument for theism: God's existence and the immortality of the soul can, Kant suggests, be defended as postulates of practical reason. The moral law (categorical imperative) does not presuppose theism but it does urge us to pursue the "highest good" (summum bonum) in which duty and happiness are in harmony. In order to be fully committed to morality, we have to presuppose God's existence and immortality. Religion is not the basis of morality but is itself based on the requirements of the moral law, particularly the highest good.

I cannot examine in any close detail the way in which Kant constructs his moral argument for the existence of God and the immortality of the soul in the "Canon of Pure

\footnotetext{
${ }^{4}$ See Immanuel Kant, Kritik der reinen Vernunft (A = 1st ed., 1781; B = 2nd ed., 1787), ed. Raymund Schmidt (Hamburg: Felix Meiner, 1990), especially the section "The Ideal of Pure Reason" in the "Transcendental Dialectic".
} 
Reason" ${ }^{\prime 5}$ and in the Dialectics of the second Critique. ${ }^{6}$ Rather, I will introduce the basic point of this argument by briefly taking up the question concerning the metaphysical status of Kant's postulates. It is clear that, as mere ideas of pure reason ("transcendental ideas"), the concepts of God and the soul according to Kant lack "objective reality". At best, these ideas can be employed regulatively, not constitutively. Their employment is very different from, say, the concept of causality, which is constitutive of possible cognitive experience and its objects (as a pure concept of the understanding, that is, as one of Kant's twelve categories). This, however, is only the point of view that theoretical, speculative reason offers to the matter. From the perspective of practical reason - which, famously, is ultimately "prior to" theoretical reason in Kant's system $^{7}$ - there is indeed some kind of "reality" corresponding to these concepts (or ideas).

The epistemic status of these concepts, when transformed into postulates of practical reason, is, to be sure, quite different from the status of the actual constitutive, transcendental conditions of any humanly possible experience, such as the pure concepts or categories of understanding and the forms of pure intuition (space and time). ${ }^{8}$ We may say that the latter kind of concepts necessarily structure, according to Kant, the (or any) human, experienceable, cognizable world, that is, any objects or events we may conceivably encounter in this world. There would be no world of objects at all, at least no world we would be able to cognitively represent, in the absence of such structuring principles and categories. However, the postulates of practical reason also structure - in an analogical though definitely not identical manner - the human world as a world of ethical concern, deliberation, and action. The key idea here is that this "structuring" is not "merely ethical" but also metaphysical: the postulates of God and the immortal soul are, Kant believes, needed to structure the human world. Another key idea is that this structuring is, because of its uniquely ethical and metaphysical status, also transcendental.

Frederick Beiser has offered one of the most insightful interpretations of Kant's defense of "moral faith" as a genuinely metaphysical perspective on the reality of God and the immortal soul. He insists, against a number of commentators viewing Kant's philosophy of religion in a deflated "thisworldly" and immanent manner - that is, avoiding any commitment to a metaphysical supernatural reality - that Kant's notion of the highest good, or summum bonum, is

\footnotetext{
${ }^{5}$ See ibid., A795/B823ff.

${ }^{6}$ See Immanuel Kant, Kritik der praktischen Vernunft (1788), in Kant, Werke in Zehn Bänden, ed. Wilhelm Weischedel (Darmstadt: Wissenschaftliche Buchgesellschaft, 1983), A223ff.

${ }^{7}$ Cf. ibid., A215ff. Here, the word "ultimately" - my word in this context rather than Kant's - is crucial, because we can observe the priority of practical reason only after having done a good deal of work of theoretical reason, that is, after having become convinced of the futility of the speculative theistic proofs and having thus seen the need for a different, pragmatic, approach.

8 These are, of course, explored in the "Transcendental Analytic" and the "Transcendental Aesthetic" of Kritik der reinen Vernunft.
} 
irreducibly theological, quite explicitly derived from the Christian tradition, especially Augustine and the idea of a "City of God". ' These notions, after all, also refer to a situation in which there is a harmony between the duties set by the moral law and the happiness of moral agents acting on the basis of, or out of respect toward (i.e., not merely in accordance with), this law. Beiser accurately summarizes Kant's argumentation as follows:

1. We have a duty, set by the moral law, to promote the highest good (summum bonum).

2. We have to presuppose the conditions for the possibility of the highest good.

3. God's existence is a condition for the possibility of the highest good.

4. Therefore, we have to presuppose the existence of God. ${ }^{10}$

I am not saying that Kant's argument is sound, but I do think that Beiser's reading captures its essential features. We should now see how this strategy of arguing for the reality of God on moral grounds - rather than vice versa - has been employed and critically modified in the pragmatist tradition.

\section{Pragmatist philosophy of religion: William James}

Pragmatists are generally not Kantians, but an argument analogous to Kant's defense of the postulates of practical reason plays an important role in William James's pragmatist philosophy of religion. In order to be seriously committed to morality, an individual may, according to James, need a religious perspective on life. James argued in The Will to Believe (1897) that we have a right to believe in the "religious hypothesis" at our own risk, if it is a genuine - that is, "live", "forced", and "momentous" - option that cannot be decided for or against on the basis of evidence. ${ }^{11}$ In a later work, Pragmatism (1907), he sketched a method of determining the true pragmatic content of our metaphysical and religious ideas by tracing out their (conceivable)

\footnotetext{
${ }^{9}$ See Frederick C. Beiser, "Moral Faith and the Highest Good", in Paul Guyer (ed.), Cambridge Companion to Kant and Modern Philosophy (Cambridge: Cambridge University Press, 2006), especially pp. 593-599. See Kritik der reinen Vernunft, A810-811/B838-839, for Kant's own characterization of the summum bonum.

10 Beiser, "Moral Faith and the Highest Good", p. 604. (This is not a direct quotation of Beiser's formulation of Kant's argument but my own paraphrase.) See Kant, Kritik der praktischen Vernunft, A223-237. See also Peter Byrne, Kant on God (Aldershot: Ashgate, 2007), especially chs. 5-6, for a critical perspective on Kant's arguments for moral faith - a perspective very different from Beiser's.

${ }^{11}$ William James, The Will to Believe and Other Essays in Popular Philosophy (1897), eds. Frederick H. Burkhardt, Fredson Bowers, and Ignas K. Skrupskelis (Cambridge, MA and London: Harvard University Press, 1979). The title essay, "The Will to Believe" (ch. 1), was first presented as a famous lecture in 1896.
} 
practical - particularly ethical - consequences. ${ }^{12}$ This, on my reading, yields an ethical evaluation and reconstruction of any pragmatically acceptable metaphysical postulations.

An example taken from James's Pragmatism may serve to illustrate this. James argues that the metaphysical (and theological) dispute between theism and atheism (or, as James also calls them, spiritualism and materialism) would be completely empty, if there were no future experiences to be expected. Construed as traditional metaphysical alternatives, both atheism and theism make the mistake of presupposing a "ready-made" and "finished" world, complete as it is. With no future experiences to be expected, the dispute between these views is "purely verbal", "quite idle and insignificant": "Matter and God in that event mean exactly the same thing - the power, namely, neither more nor less, that could make this completed world..."13 These views, however, entail quite different expected outcomes for the world. They "promise" quite different things regarding the future of the world. Those expectations and promises can only be examined in relation to human life and its moral possibilities. The rival metaphysical (and theological) positions must be evaluated in terms of their ability to help us live - and live forward, facing our futures - in this world. In this respect, theism is, James argues, preferable to materialistic atheism. It makes better moral sense of the world and its future.

Kant's and James's arguments can be compared. Kant's argument again, in nuce, is the following. Human moral pursuits (i.e., pursuing what the moral law requires, or more specifically, pursuing the "highest good") are possible only if God exists (and, mutatis mutandis, if we possess an immortal soul). Now, human moral pursuits are possible (because actual). Therefore, God exists (and, mutatis mutandis, we possess an immortal soul). James's argument is structurally similar. He also believes that human moral pursuits (i.e., "morally strenuous living" or the "morally strenuous mood" of life $)^{14}$ are possible, in a full, serious, and "energized" sense, only if God exists. He further maintains - though with some hesitation and uncertainty - that human moral pursuits are possible (because actual). Therefore, he also concludes, or at least gives us the "right" to conclude, that God exists.

From a Jamesian pragmatist point of view, as much as from the Kantian one, ethics and metaphysics then seem to be profoundly entangled. Religion, or theism, is pragmatically legitimated as a postulate needed for morality, for our ethical life and practices. Yet, no theological ethics in the style of, say, divine command theory can be rationally accepted by a critical moral philosopher. It would amount to putting the cart before the horse to hold that

\footnotetext{
12 William James, Pragmatism: A New Name for Some Old Ways of Thinking (1907), eds. Frederick H. Burkhardt, Fredson Bowers, and Ignas K. Skrupskelis (Cambridge, MA and London: Harvard University Press, 1975), especially ch. 3.

13 Ibid., pp. 51-52.

14 Phrases such as these occur repeatedly in James's writings, including The Will to Believe and Pragmatism.
} 
ethics could be grounded in or based upon theology (or religious revelation). What we need, according to both Kant and James, is moral theology - a theology based on ethics, rather than vice versa. Any attempt to base ethics on theology, or religion, would be an example of heteronomy instead of autonomy (in Kantian terms), but the only critical and rational way to provide a basis for theology is the ethical way. In particular, toward the end of Pragmatism, James discusses in detail the need for a "melioristic" understanding of religion as an energizing source for the moral challenges of human life: we are unable to offer any metaphysical grounding for our religious ideas and hopes, but such ideas and hopes may themselves act as the morally enabling (yet never certain or infallible) sources of ethically serious human life. ${ }^{15}$

However, there are important differences between Kant and James. We may locate the possible divergence of their argumentative strategies in the following crucial question: is theism (or what James occasionally calls the "theological postulate") here practically (pragmatically) legitimated a priori, by reason's capacities only (as it definitely is in Kant), or does it receive its legitimation empirically or psychologically, as an attitude de facto "energizing" moral life, because we are the kind of beings we are (as the matter seems to be in James)? My suggestion here is that just as Kantian transcendental (critical) philosophy more generally synthesizes the pre-critically opposed epistemological doctrines of empiricism and rationalism, and just as pragmatism attempts to bridge various other philosophical gaps, including the one between facts and values, ${ }^{16}$ we may try to reconcile Kantian (transcendental) and Jamesian (pragmatist, empirical, psychological) ways of justifying theism ethically. ${ }^{17}$

I am not saying that such arguments will inevitably or immediately succeed; that would be a much more ambitious claim. What I am suggesting is that the Kantian moral defense of theism in terms of Kant's conception of postulates of practical reason is, when flexibly interpreted, open to a pragmatic (Jamesian) rearticulation, and that the thus rearticulated pragmatic theism must not be thoroughly disconnected from the Kantian transcendental work of practical reason. Indeed, James's pragmatism itself is open to a Kantian recontextualization. Both the Kantian and the Jamesian pragmatist should view theism as, primarily, a problem of human moral life. For both, the ultimate question is the ethical basis of theistic (or, for that matter, atheistic) metaphysics. For neither can the theism issue be resolved in total absence of ethical considerations.

\footnotetext{
15 James, Pragmatism, ch. 8.

${ }^{16}$ See Hilary Putnam, The Collapse of the Fact/V alue Dichotomy and Other Essays (Cambridge, MA and London: Harvard University Press, 2002); Putnam, Ethics without Ontology (Cambridge, MA and London: Harvard University Press, 2004); as well as Sami Pihlström, Pragmatic Moral Realism: A Transcendental Defense (Amsterdam and New York: Rodopi, 2005).

${ }^{17}$ For a more comprehensive discussion of this possibility, see Pihlström, Pragmatic Pluralism and the Problem of God, especially ch. 2 .
} 


\section{Naturalized pragmatist philosophy of religion: John Dewey}

John Dewey offers, in his A Common Faith (1934), a version of pragmatist philosophy of religion quite different from James's - a conception of religiosity "naturalized". He argues that it is crucial to distinguish between (historical, dogmatic) religions and the religious as a quality of experience, which may be related to virtually any kind of experience (scientific, moral, aesthetic, political, ...). Again, religion cannot be the ground of ethics or politics but must itself be evaluated on ethical and political grounds. A naturalized account of religious experience is pragmatically preferable to any supernaturalist metaphysics, which usually leads to dogmatism and political discrimination.

As Dewey puts it in A Common Faith, religious values can be "inherent in natural experience" (LW9:20). "Any activity pursued in behalf of an ideal end against obstacles and in spite of threats of personal loss because of conviction of its general and enduring value is religious in quality" (LW9:19). "The religious" must be liberated from the supernatural commitments of actual historical religions, from dogmas and doctrines that are, pragmatically, unnecessary. The values and ideals belonging to the religious attitude are not imaginary but real; they are "made out of the hard stuff of the world of physical and social experience" (LW9:33). The religious is, through this rearticulation, rendered part of nature - which, for Dewey, is allencompassing. ${ }^{19}$

The basic contrast thus lies between religions and "the religious" (that is, religious experience, or religious qualities or aspects in experience). The proton psendos of both traditional religions and militant atheism opposed to any kind of religiosity is the identification of the religious with the supernatural, which disentangles religiosity from life. Religion must be brought down to earth, to what is "common" between us. Supernaturalism - especially the claim that

\footnotetext{
${ }^{18}$ I am citing Dewey's work in the standard manner. The reference is to The Collected Works of John Dewey: The Late Works (LW), ed. Jo Ann Boydston (Carbondale: Southern Illinois University Press, 1966-1987). LW9 stands for The Late Works, vol. 9 (1986).

${ }^{19}$ For discussions of this basic message of $A$ Common Faith, see Stephen C. Rockefeller, Jobn Dewey: Religious Faith and Democratic Humanism (New York: Columbia University Press, 1991), chs. 10-11; Michael Eldridge, Transforming Experience: John Dewey's Cultural Instrumentalism (Nashville, TN: Vanderbilt University Press, 1998), ch. 5; Larry Hickman, "Cultivating a Common Faith: Dewey's Religion", in Hickman, Pragmatism as Post-Postmodernism: Lessons from John Dewey (New York: Fordham University Press, 2007), ch. 11; and Sami Pihlström, "Dewey and Pragmatic Religious Naturalism", in Molly Cochran (ed.), The Cambridge Companion to Dewey (Cambridge: Cambridge University Press, 2010), pp. 211-241. Many interpreters have argued that Dewey's main interest in A Common Faith is not religion as such, but social progress, democracy, and other more this-worldly topics on which he wrote voluminously elsewhere. However, for a comprehensive treatment of Dewey's theological relevance - even for Deweyan pragmatism as a theological methodology - see Jerome Paul Soneson, Pragmatism and Pluralism: John Dewey's Significance for Theology (Minneapolis: Fortress Press, 1993.
} 
religions have a monopoly of supernatural means to further human ideals - is an obstacle in pursuing the natural changes that are in our power to bring about; hence, religious values need emancipation (LW9:19-24, 38-39, 45, 50-53). ${ }^{20}$ This is how Dewey contrasts his proposal to the quarrels between religious and scientific ideas:

I shall develop another conception of the nature of the religious phase of experience, one that separates it from the supernatural and the things that have grown up about it. I shall try to show that these derivations are encumbrances and that what is genuinely religious will undergo an emancipation when it is relieved from them; that then, for the first time, the religious aspect of experience will be free to develop freely on its own account. (LW9:4.)

Thus, Dewey is about to tell us what is "genuinely religious" - apparently in contrast to what is pseudo-religious or superstitious. The key to this normative distinction lies, again, in the difference between (a) religion(s) and the religious. A religion is "a special body of beliefs and practices having some kind of institutional organization", whereas "religious", as an adjective, does not denote any specific entity but "attitudes that may be taken toward every object and every proposed end or ideal" (LW9:8). Many elements of actual religions survive from "outgrown cultures" (LW9:6). We should leave such baggage behind, as religions largely "prevent $[\ldots]$ the religious quality of experience from coming to consciousness and finding the expression that is appropriate to present conditions, intellectual and moral" (LW9:8) particularly to modern scientific thinking. Dewey, then, is not proposing $a$ religion at all but "the emancipation of elements and outlooks that may be called religious" (LW9:8).

Dewey is above all speaking about religious experience, which is well in line with his more general project of raising experience into the status of a fundamental philosophical category. However, Deweyan religious experience is social - his conception of the religious articulates a "common faith" - rather than individual, as in the equally experience-centered philosophy of religion of his fellow pragmatist, James. ${ }^{21}$ More importantly, religious experience,

${ }^{20}$ Cf. also Dewey, “One Current Religious Problem” (1936), LW11:115-117; “Anti-Naturalism in Extremis” (1943), LW15:49-62, especially p. 56; and "Contribution to 'Religion and the Intellectuals"' (1950), LW16:390-394. The emancipatory project of $A$ Common Faith and these related writings is somewhat analogous to the project of liberating aesthetic experience as a natural form of human experiencing in Art as Experience (1934, LW10).

21 See William James, The Varieties of Religious Experience: A Study in Human Nature (1902), eds. Frederick H. Burkhardt, Fredson Bowers, and Ignas K. Skrupskelis (Cambridge, MA and London: Harvard University Press, 1985). 
for Dewey, is not a special type of experience. It is not sui generis. ${ }^{22}$ As a quality of experience, "religious" can be connected with aesthetic, scientific, moral, or political experience, ${ }^{23}$ as well as with experiences of companionship and friendship (LW9:9). Whenever there is "a change of will conceived as the organic plenitude of our being", there is a religious attitude, outlook, or function (LW9:13). Thus, "whatever introduces genuine perspective is religious" (LW9:17).

As Deweyan religious experience is in and of nature, the attitude which "attributes human achievement and purpose to man in isolation from the world of physical nature and his fellows" is "essentially unreligious" (LW9:18). Thus, a paradigmatic case of a non- or even pseudo-religious way of thinking, for Dewey, is an individualist, supernaturalist account of spirituality isolated from other individuals' experience and concerns. Conversely, the paradigmatic case of a social enterprise carrying religious qualities is science, whose methods Dewey sought to incorporate into moral and political "inquiries". "Faith in the continued disclosing of truth through directed cooperative human endeavor is more religious in quality than is any faith in a completed revelation", Dewey argues (LW9:18). Our "faith in intelligence" may, then, become religious in quality (LW9:19). Here Dewey arrives at his famous definition, concluding the first chapter of A Common Faith: "Any activity pursued in behalf of an ideal end against obstacles and in spite of threats of personal loss because of conviction of its general and enduring value is religious in quality" (LW9:19).

As the argument unfolds, Dewey reaffirms his trust in the "new methods of inquiry and reflection" as having become "the final arbiter of all questions of fact, existence, and intellectual assent" (LW9:22-23). The scientific method can accept nothing as sacrosanct, beyond critical testing (LW9:27-28). There is no return to any pre-scientific revealed religion. Dewey characterizes "faith" as "the unification of the self through allegiance to inclusive ideal ends, which imagination presents to us and to which the human will responds as worthy of controlling our desires and choices" (LW9:23). Again, there is no need to view the ideal ends as supernatural: "The assumption that these objects of religion exist already in some realm of Being seems to add nothing to their force, while it weakens their claim over us as ideals, in so far as it bases that claim upon matters that are intellectually dubious." (LW9:29; cf. 32-33.) Yet, the "reality" of ideal ends and values is unquestionable. Dewey offers a pragmatic argument: it is "unnecessary" for the religious attitude to rely on supernatural dogma. Values arise from nature,

\footnotetext{
${ }^{22}$ Rockefeller, John Dewey, p. 472. One contrast perceived by Rockefeller is to Rudolf Otto's influential theory of "the holy".

23 Thus, in "Religion in the Soviet Union" (1930), Dewey referred to communism as having the character of a religious faith (LW5:356-357). The fruits of religious experiences need not always be positive.
} 
having their roots in "natural conditions", emerging through imagination's "idealizing" existence (LW9:33).

One of the imaginatively projected ideals dear to many is the idea(l) of God, reinterpreted by Dewey as the "active relation between ideal and actual" (LW9:34; original emphasis). Dewey adds, however, that he would not insist that the name "God" must be given to this (or anything) (LW9:34-35). He seems to suggest that if we speak about God, this is how we should do it: scientifically, naturalistically, immanently, not dogmatically or supernaturalistically. This position is compatible with our not using the concept "God". Yet, Dewey wanted to make room for our use of that concept, to understand people who cannot help using it. ${ }^{24}$ The concept of God as a relation between the ideal and the actual also helps us to overcome the "lack of natural piety" that "militant atheism" suffers from:

A religious attitude [...] needs the sense of a connection of man, in the way of both dependence and support, with the enveloping world that the imagination feels is a universe. Use of the words "God" or "divine" to convey the union of actual with ideal may protect man from a sense of isolation and from consequent despair or defiance. (LW9:36.)

This way of reconceptualizing the divinity enables Dewey to connect his reflections with his view of continuous growth as our highest goal. The growth of knowledge in scientific inquiry, or "growth in understanding of nature", may also be religious in its aims and aspirations (LW9:38). After all, the study of the mysteries of creation has often been viewed as a fundamentally religious activity.

Toward the end of his book, Dewey considers at some more length the social relevance of his conception of faith. He argues that there is no need to "shut religious values up within a particular compartment" - to draw a sharp division between the religious, on the one side, and the secular or profane, on the other (LW9:44-45). ${ }^{25}$ The liberation of the religious from narrow supernaturalism is ethically and socially, even politically, relevant:

\footnotetext{
${ }^{24}$ He writes: "Whether one gives the name 'God' to this union, operative in thought and action, is a matter for individual decision. But the function of such a working union of the ideal and actual seems to me to be identical with the force that has in fact been attached to the conception of God in all the religions that have a spiritual content; and a clear idea of that function seems to me urgently needed at the present time." (LW9:35.)

25 This suggestion might be compared to analogous pragmatist accounts in moral philosophy: morality, or moral experience, is so ubiquitous in human practices that it should not be "compartmentalized" in its own special department. Moral values pervade our existence as a whole; experience comes to us "screaming with values", as Hilary Putnam often quotes Dewey as saying. See Putnam, Ethics without Ontology; see also Pihlström, Pragmatic Moral Realism (cited above).
} 
I cannot understand how any realization of the democratic ideal as a vital moral and spiritual ideal in human affairs is possible without surrender of the conception of the basic division to which supernatural Christianity is committed. Whether or not we are, save in some metaphorical sense, all brothers, we are at least all in the same boat traversing the same turbulent ocean. The potential religious significance of this fact is infinite. (LW9:55-56.)

We have the potential to grow, struggling together toward the actualization of ideals, instead of assuming that our ideals are "already embodied in some supernatural or metaphysical sense in the very framework of existence" (LW9:56). While James, as we saw, seems to defend a theistic metaphysics based on ethical considerations (cf. the previous section), Dewey's philosophy of religion is more clearly anti-metaphysical: there is no such thing as "the very framework of existence", because existence itself emerges in and through human idealdriven inquiries. Yet there is a tension here. Dewey, as a good naturalist, does seem to subscribe to something he describes as "the mysterious totality of being the imagination calls the universe" (LW9:56). There is, after all, the natural universe, giving rise to any human values and ideals there may be. Religious qualities of experience are inherently related to this mysterious nature, or the awe we feel when realizing that we are parts of it, and its growth.

Whereas James already took important steps away from Kant (albeit maintaining the basic idea that religion must be grounded in morality rather than the other way round), Dewey is already very far from Kant (though of course also agrees with him in rejecting any religious or theological foundations for morality). Yet, again, James and Dewey should also be critically compared from the perspective of the key issue concerning the relation between religion and morality. Both pragmatists examine religion ethically - advancing something like moral theology, instead of theological ethics. Their discussions are also connected with political issues of religious equality: Dewey's A Common Faith is an excellent formulation of a position taking very seriously religious equality in a multicultural society. However, despite its antidogmatism, one may argue from a Jamesian perspective that it suffers from a kind of monism (that is, naturalism). Dewey's religious naturalism might therefore need to be subordinated to, or contextualized within, Jamesian pragmatic pluralism: James's pluralism enables us to evaluate ethically any philosophy of religion, including Deweyan naturalism. This brief observation, which I cannot here develop further, should lead us to appreciate the perhaps increasing relevance of pragmatism in contemporary debates over religious equality, pluralism, and multiculturalism. 


\section{Neopragmatist philosophy (and critique) of religion: Richard Rorty}

While the classical pragmatists (Peirce, James, Dewey) were to some extent sympathetic to religion, neopragmatists like Richard Rorty have been much more sharply critical of religion. ${ }^{26}$ The classical pragmatists (James, in particular) can be interpreted as offering their own versions of the Kantian "moral argument" for God's reality, but Rorty clearly cannot. According to Rorty's radically neopragmatist characterization of what he calls "post-Philosophical culture", "[...] when the secret police come, when the torturers violate the innocent, there is nothing to be said to them of the form 'There is something within you which you are betraying. Though you embody the practices of a totalitarian society which will endure forever, there is something beyond those practices which condemns you." ${ }^{27}$ Rorty admits that this thought is "hard to live with", as in the post-Philosophical culture we finally realize that we are "alone, merely finite, with no links to something Beyond". ${ }^{28}$

This is part of Rorty's general project of "de-divinization", of thoroughgoing atheism applied not just to religion but to all other areas of culture, including philosophy in particular. When the secret police arrives, there is nothing transcendent - nothing in human history, and nothing deep down in the human mind (or soul) - that would or even could condemn their torturous practices. Insofar as it is an essential feature of totalitarianism that individuals qua individuals are made superfluous, ${ }^{29}$ totalitarian practices aiming at such destruction of individuality are simply among the many human practices and "vocabularies" there are, none of which is objectively correct or incorrect from a super-perspective beyond those practices and vocabularies.

There is, moreover, nothing over and above the contingent historical clashes of practices and vocabularies - clashes that are, in the end, merely causal, instead of being rational or normative. Even Rorty's own claims are presumably also only intended to make this rhetorical (causal) effect on the ways we talk, instead of standing in any normative, argumentative, or justificatory relation to the ways we should talk. ${ }^{30}$ Any candidate for such trans- or ahistorical transcendence would be guilty of an unpragmatic quasi-theological metaphysics that the Rortyan liberal ironist - however strongly committed to preserving liberal and democratic values - sets

\footnotetext{
${ }^{26}$ However, Hilary Putnam's neopragmatism is more sympathetic to religion: cf. Putnam, Jewish Philosophy as a Guide to Life (Bloomington: Indiana University Press, 2008).

${ }^{27}$ Richard Rorty, Consequences of Pragmatism (Brighton: Harvester Press, 1982), pp. xlii-xliii.

${ }^{28}$ Ibid.

${ }^{29}$ Cf. Hannah Arendt, The Origins of Totalitarianism (San Diego: Harcourt, 1979; first published 1951).

${ }^{30}$ It is highly unclear whether this position can be coherently maintained - but then again, does coherence matter if the primary purpose is rhetorical persuasion?
} 
aside as a remnant of the theological past of humanity. Thoroughgoing atheism, or antitheology, is thus connected with radical anti-metaphysics. Appeals to truth, humanity, history, conscience, personhood, or guilt are just quasi-secular counterparts of appeals to God, and they are therefore of no use when the secret police comes.

It is, however, possible to challenge this Rortyan line of thought and to thereby examine the possibility of a pragmatist metaphysics (including theology) that takes seriously the ethical need to actually live with the metaphysical and/or theological pictures (or their criticism) emerging in the course of our lives and practices. We may here contrast Rorty's pragmatism with James's (and even with Dewey's, though Rorty clearly prefers Deweyan naturalism to Jamesian more religiously oriented pragmatism). As should be clear after our discussion of Kant's postulates of practical reason as well as James's and Dewey's twists to the Kantian conception of the primacy of practice, the ethical - including the ethical evaluation of religion - is not simply non-metaphysical.

When Rorty says that his post-Philosophical utopia is hard to live with, it is easy to agree with him: a pragmatist position is seriously defective, if it prevents us from truly living with the views it advances. From a pragmatist perspective, metaphysical and religious or theological views (ideas, theories, positions) should be evaluated in terms of their ability to help us live especially, to help us live ethically. This conception of pragmatist metaphysics is, arguably, central in James's pragmatism, in particular; metaphysics (and theology), as pragmatically conceived, has an ethical core, or ethical grounds. A pragmatist metaphysics or theology must be able to oppose, e.g., totalitarian attempts to make human beings superfluous as individuals.

From the perspective of Jamesian pragmatism and its account of the ethical grounds of metaphysics, in particular, we should formulate an ethical norm for any pragmatically adequate or acceptable metaphysical and theological theorizing and reflection: we are entitled to, or even pragmatically (ethically) required to, commit ourselves to such metaphysical and/or theological views of humanity, history, the soul, etc. (or virtually anything that Rorty finds a mere counterpart of religious ideas) that will enable us to "respond to the secret police", to condemn the torturer. This is not just to claim that there are "moral reasons" for our actions independent of our individual perspectives (etc.), which just amounts to standard moral realism, but to claim, more strongly, that there are moral reasons to accept or reject certain metaphysical or theological views. For example, James would argue that monism is morally dangerous and therefore not only ethically but also metaphysically and theologically unacceptable, given that metaphysics and theology is pragmatically answerable to ethics (cf. above). ${ }^{31}$

\footnotetext{
${ }^{31}$ Cf. James, Pragmatism, ch. 4. As we saw above, James's defense of theism is thoroughly ethically motivated.
} 
It is, indeed, a basic Jamesian premise that we have a duty to recognize, or acknowledge, the suffering of those who were (or are) visited by the secret police - to take seriously others" perspectives. As James frequently pointed out, we must not be "deaf to the cries of the wounded". We must be able to hear the individual voices of suffering human beings - e.g., against totalitarian attempts to make them superfluous - and we must also use whatever metaphysical and theological means we have at our disposal to console the victims and to condemn their torturers.

Pragmatist metaphysics cannot simply rely on any religious or other "spiritual" convictions - here we should of course agree with Dewey and Rorty - but it may arrive at such convictions as a result of a careful pragmatic consideration of what kind of potential responses we are really able to live with in an ethically responsible way. Thus, something like "moral religion" or moral theology might (but of course need not) in the end emerge from the pragmatist grounding of metaphysics in ethics, as was already observed in relation to Kant's and James's views above.

Richard Bernstein calls Rorty's position deep humanism, capturing its key idea in the recognition that we can appeal to no "outside authority" such as God, Truth, or Reality, i.e., that there is "nothing that we can rely on but ourselves and our fellow buman beings". ${ }^{2}$ This somewhat "toughminded" (to use a Jamesian term) "self-reliance" (to use an Emersonian term also employed by Rorty himself) is a key idea in pragmatism which has given up dogmatic, infallibilist beliefs in authorities and is willing to reinterpret our fundamental philosophical notions such as truth and reality from a thoroughly human perspective. Yet, in some cases our "deep humanism" should let us transcend not only our context, vocabulary, or ethnos, but also everything merely human. Our reliance on our fellow human beings requires us to take seriously their "voices", especially the "cries of the wounded" - voices and cries that often reach out for something beyond the merely human - and thus to take metaphysics and theology seriously.

Moreover, a commitment to (or a reaching out for) something transcendent may in some cases be a precondition for our ability to engage in some "deeply human" practices, for instance, religion. A truly deep humanism must also allow for the "tender-minded" aspects of our reliance on ourselves and others, aspects that at least in some important cases may amount to steps toward transcendence. I doubt that Rorty's “deep humanism” sufficiently acknowledges this. ${ }^{33}$ In contrast, we should here, again, look back at James's philosophy of religion: reaching

\footnotetext{
32 See Richard J. Bernstein, The Pragmatic Turn (Cambridge: Polity Press, 2010), p. 211. See also ch. 9 passim.

${ }^{33}$ For a more comprehensive critical treatment of Rorty's views on religion, see Sami Pihlström, "Rorty on Faith and Hope: Comparative Perspectives on Neopragmatist Philosophy of Religion", Philosophy Today 1 (2010), online: http://www.pragmatismtoday.eu/summer2010/Pihlstrom-Rorty on Faith and Hope.pdf.
} 
out for transcendence is something that takes place, or something we do, on the basis of human needs and interests, from within human practices and their ethical concerns. Metaphysical theories of the transcendent must be evaluated in terms of their ethical results. ${ }^{34}$

\section{Concluding remarks: the importance of negative moral concepts}

However, not just any kind of metaphysical or religious "consolation" is ethically acceptable. Our discussion must at this point acknowledge the fundamental importance of "negative" moral concepts such as guilt, evil, etc. An ethically adequate metaphysics or theology must reserve a central place for these notions. The pragmatist cannot avoid reflecting on the problem of evil, either. For James this is a much more central concept than it might initially appear, if one just takes a shallow look at his "melioristic" pragmatism. Evil - and the need to avoid the theodicies postulated by the absolute, monistic idealisms of James's times, which he finds unethical - plays a key role in Pragmatism and elsewhere. ${ }^{35}$

This ethical need to take evil, suffering, guilt, and other "negative" moral concepts and phenomena very seriously, that is, the need to avoid offering any pseudo-consolation to the "wounded" whose voices we must hear, shows that there is a deep relation between ethics and religion, even though the former can never be based on the latter. Without appreciating this connection, we fail to appreciate the profundity of the moral obligation itself. There are several dimensions to, and examples of, this analogy between ethics and religion, going beyond the Kantian and pragmatist moral theology discussed above. In particular, the ethical requirement of avoiding any theodicies (or "antitheodicism", as I propose to call it), ${ }^{36}$ should be extended to secular versions of theodicies, too, such as the Hegelian (or pseudo-Hegelian) views that the world-historical development of the Spirit will eventually heal any wounds that the twists and turns of history may accidentally produce. No, they won't. There is always something bitter at the bottom of the cup of life, as James suggested toward the end of Pragmatism, returning in the final pages of the book to evil, suffering, loss, and tragedy:

\footnotetext{
${ }^{34}$ James, Pragmatism, chs. 3-4.

${ }^{35} \mathrm{I}$ have elsewhere argued for a reading of James emphasizing the need to acknowledge the reality of evil: see Sami Pihlström, "The Trail of the Human Serpent Is over Everything": Jamesian Perspectives on Mind, World, and Religion (Lanham, MD: University Press of America [Rowman \& Littlefield Publishing Group], 2008), ch. 4.

${ }^{36}$ See Sami Pihlström, "The Problem of Evil and the Limits of Philosophy: Toward a Pragmatist Appreciation of the Impossibility of Theodicies", forthcoming in Graduate Faculty Philosophy Journal (2012).
} 
In particular this query has always come home to me: May not the claims of tendermindedness go too far? May not the notion of a world already saved in toto anyhow, be too saccharine to stand? May not religious optimism be too idyllic? Must all be saved? Is no price to be paid in the work of salvation? Is the last word sweet? Is all 'yes, yes' in the universe? Doesn't the fact of 'no' stand at the very core of life? Doesn't the very 'seriousness' that we attribute to life mean that ineluctable noes and losses form a part of it, that there are genuine sacrifices somewhere, and that something permanently drastic and bitter always remains at the bottom of its cup?

I cannot speak officially as a pragmatist here; all I can say is that my own pragmatism offers no objection to my taking sides with this more moralistic view, and giving up the claim of total reconciliation. [...] It is then perfectly possible to accept sincerely a drastic kind of a universe from which the element of 'seriousness' is not to be expelled. Whoso does so is, it seems to me, a genuine pragmatist. $^{37}$

There are, then, real losses. But there may, therefore, be real gains as well. The Jamesian pragmatist should be equally appreciative of both, and so should anyone wishing to ground religion in its ethical aspects (rather than the other way round).

The seriousness of the anti-theodicist attitude is comparable to the fundamental seriousness often attached to the religious perspective on life. In this sense, ethics is, again, something that is of ineliminable importance to us in a very special sense. Only religion - not science, for instance, nor arguably even art - can offer an analogy of that kind of seriousness. Not only the religious believer but the non-believer as well should also be able to appreciate this line of thought, yielding the observation that morality and religion may in the end be considerably closer to each other than we usually want to admit in our secular culture. We cannot appreciate the infinity of our moral duty and our constant failure to be moral without appreciating this crucial link. ${ }^{38}$ There is a kind of depth in the concept of evil which presupposes that we take seriously the religious background ideas framing such concepts. They must be understood in order to retain the full (potential) meaning of that concept in our attempts to understand the human condition.

\footnotetext{
${ }^{37}$ James, Pragmatism, pp. 141-142.

${ }_{38}$ See, for more details, my recent book, Transcendental Guilt: Reflections on Ethical Finitude (Lanham, MD: Lexington Books [Rowman \& Littlefield Publishing Group], 2011).
} 
We might say that, in facing our ethical duty, or in realizing (with horror) that we haven't been able to face it in the way we ought to, we stand before God - whether or not we believe God to be real in some traditional metaphysical or theological sense - at least in the sense that our duty, if it is ethical at all, is inescapable and potentially unlimited. That is, any fact in the human world challenges us ethically. ${ }^{39}$ Moreover, this formulation could be connected with a broader view shared by as different philosophical orientations as, say, pragmatism and phenomenology (both of which were, in different ways, influenced by Kantianism): the way the world is for us - the way it is given to us - is not as a collection of objects of mere representation and/or spectation but as a field of activity and experience. Thus, the human world is a "field" of moral engagement even in the absence of specific moral actions, also when we just set out to contemplate the world religiously or metaphysically.

I would like to conclude by suggesting that the "theodicist" claim that "all is well" - that there is in reality no evil, or that whatever evil there is is explained away and/or justified within a monistic theistic scheme - is the other side of the coin of the Rortyan de-divinization discussed above. Neither can adequately (or at all) respond to the secret police. Theodicies do not take the task of responding seriously, because "all is well" - nothing really needs to be done - while Rortyan ironism surrenders without being able to respond at all. Pragmatist philosophy of religion, like Kantianism, requires an active response based on a continuous ethical struggle for a better world. Pragmatic meliorism must, however, be based on a full recognition of the reality of evil - and it is right here, at the heart of these negative moral concepts, that the fundamental link between ethics and religion must be appreciated.

Finally, we may pause to reflect on what it actually means to evaluate religious and theological (or, presumably, any metaphysical) commitments ethically (as I have argued that the pragmatists have done - following Kant in this - and as I have urged throughout this essay that we should do). We cannot engage in such evaluation on the basis of any pre-given, substantial ethical theory - nor of any purely formal one - because what is given to us here is the ethical requirement to autonomously evaluate our own life, including our commitment to ethical theories and religious beliefs. We must, then, evaluate our commitments from within those commitments themselves, whatever they are. This is, inevitably, a reflexive self-evaluation. In the end, our entire life must be at stake in this process, which again brings ethics and religion together in the deep way pictured above.

Furthermore, autonomous evaluation is also committed to stepping forward in order to place oneself into a process of evaluation by others. Any substantial ethical views, or

\footnotetext{
${ }^{39}$ In my Transcendental Guilt (see the previous note), I try to develop the idea that, therefore, any fact may make us, or me, guilty.
} 
religious ones for that matter, can emerge only within such concrete self-critically evaluative engagements - thus in a sense always ad hoc, rather than abstractly or generally. Only then can religion be moral. ${ }^{40}$

\section{References}

Bernstein

Dewey

Dews

James

Kant

Pihlström

Putnam

Rorty

Wittgenstein

40 This paper was partly presented in the symposium, Morality - the Role of Religion and Religious Communities, at the Helsinki Collegium for Advanced Studies (March, 2011). I am grateful to the organizers - Anne Birgitta Pessi, Petri Luomanen, and Ilkka Pyysiäinen - for the kind invitation to contribute this paper to the symposium and to this volume. Parts of the paper were also presented at the New York Pragmatist Forum (Fordham University, New York City, February, 2011). 